\title{
Cashless Transactions: A Study on Intention and Adoption of e-Wallets
}

\author{
Marvello Yang ${ }^{1}$, Abdullah Al Mamun ${ }^{2, *(\mathbb{D})}$, Muhammad Mohiuddin ${ }^{3}\left(\mathbb{D}\right.$, Noorshella Che Nawi ${ }^{4}$ (D) \\ and Noor Raihani Zainol ${ }^{4}$ (D)
}

1 Department of Management, Faculty Economic and Bussiness, Widya Dharma University Pontianak, Kota Pontianak 78243, Indonesia; marvelo_yang@widyadharma.ac.id

2 Faculty of Business and Management, UCSI University, Kuala Lumpur 56000, Malaysia

3 Faculty of Business Administration, Laval University, Quebec, QC 2325, Canada; muhammad.mohiuddin@fsa.ulaval.ca

4 Faculty of Entrepreneurship and Business, Universiti Malaysia Kelantan, Kota Bharu 16100, Malaysia; norshella@umk.edu.my (N.C.N.); raihani@umk.edu.my (N.R.Z.)

* Correspondence: abdullaham@ucsiuniversity.edu.my; Tel.: +6-01-3300-3630

check for updates

Citation: Yang, M.; Mamun, A.A.; Mohiuddin, M.; Nawi, N.C.; Zainol, N.R. Cashless Transactions: A Study on Intention and Adoption of e-Wallets. Sustainability 2021, 13, 831. https://doi.org/10.3390/su13020831

Received: 1 January 2021

Accepted: 13 January 2021

Published: 15 January 2021

Publisher's Note: MDPI stays neutral with regard to jurisdictional claims in published maps and institutional affiliations.

Copyright: (c) 2021 by the authors. Licensee MDPI, Basel, Switzerland. This article is an open access article distributed under the terms and conditions of the Creative Commons Attribution (CC BY) license (https:// creativecommons.org/licenses/by/ $4.0 /)$.

\begin{abstract}
This study explored the effect of perceived usefulness, perceived ease of use, social influence, facilitating condition, lifestyle compatibility, and perceived trust on both the intention to use an e-wallet and the adoption of an e-wallet among adults by using the unified theory of acceptance and use of technology (UTAUT). This quantitative study adopted a cross-sectional research design to gather data from 501 respondents using a Google Form. The collected data were analyzed using partial least square structural equation modelling (PLS-SEM). As a result, perceived usefulness, perceived ease of use, social influence, lifestyle compatibility, and perceived trust displayed a significant positive effect on both intentions to use an e-wallet and adoption of an e-wallet. This study evidenced the mediating effect of the intention to use an e-wallet on the correlations between the predictors and adoption of an e-wallet. Both the age and gender of the respondents moderated the effect of lifestyle compatibility on intention to use an e-wallet. The study outcomes serve to inform managers and policy makers to devise effective strategies that capture consumers' intention to use and experience of using an e-wallet in the midst of a turbulent market. Ultimately, such carefully sculpted policies may promote the digital platform and web-based application, apart from encouraging higher rates of e-wallet adoption in developing countries.
\end{abstract}

Keywords: perceived usefulness; perceived ease of use; social influence; facilitating condition; compatibility; perceived trust; intention; adoption; e-wallet

\section{Introduction}

The emergence of e-commerce is a global phenomenon across developing countries. Nevertheless, the expectations in its development have not been completely met, as significant differences still exist between online and offline purchases related to e-commerce. Data-based transmission and electricity are essential support systems required to improve the security of the personal data of consumers using e-commerce. According to Bibri [1], blockchain systems may be instrumental in offering secured databases and in protecting data distribution. Smart technology networks and internet-based operation devices are essential to explore e-commerce with specific features, particularly when the device is set within the society to capture consumers' intentions.

Cashless payment via digital systems, a recent implementation of e-commerce, refers to a smart payment alternative in several developing countries to gain sustainable competitive advantage [2]. Consumption and consumer behavior are crucial factors in societies, particularly during the coronavirus disease 2019 (COVID-19) outbreak in 2020. Digitalization has been a major factor of consumer's behavior that has led to new ways of living. 
With the increasing adoption of online services, electronic payment has become more trustworthy, along with the expansion of the range of suppliers and the size of their delivery networks [3]. The emergence of digitalization through the Internet has accelerated the flow of globalization and payment systems from manual to online transactions. This has led to the dependency on electronic money (e-money) usage in performing transactions. To date, digital wallets and online transactions have addressed issues related to cash handling and long-distance transactions. In addition, e-wallets may be recharged by another similar device with money in its wallet using any mode of transaction [4]. The adoption of using e-wallets (AEW) is associated with digital currency by using internet banking, debit or credit cards, and several other payment platforms to enhance the point of sales anytime and anywhere. Moreover, e-wallets simplify purchasing and selling transactions through use of smartphone apps, which enables one to complete online shopping rapidly and without hassle. Despite these benefits, e-wallets pose security risks, demands one's device to be charged, and may lead to reckless spending [5].

This study investigated factors that motivated the Indonesian youth to use e-wallet in light of their intention to use an e-wallet and adoption of an e-wallet. Prior studies have probed the perceived usefulness, adoption of digitalization to perceived use [6], social influence [7], facilitating condition [8], lifestyle compatibility [9], perceived trust [6], and intent towards the adoption of an e-wallet [10]. In this regard, the unified theory of acceptance and use of technology (UTAUT) was initiated as the initial conceptual model to assess numerous technology adoptions [11]. The UTAUT is an essential theory related to behavior intention to use technology in an organization. Therefore, it is interesting to examine the causes of the usage of an e-wallet during this outbreak and to predict consumers' attitudes towards using the Internet during unpredictable economic changes.

\section{Context of the Adoption of e-Wallets in Indonesia}

The growth of the Internet in Indonesia had driven e-commerce from 2013 to 2020. The number of e-commerce users in Indonesia increased from $34 \%$ of the total population in 2015 to $53 \%$ in 2020 [12]. Indonesian consumers are very receptive towards new products within the digital economy sector. The growth of the market for fintech products in Indonesia has displayed an upward trend, evidenced by the increment in transaction value and the number of start-ups [13]. Recent data revealed that digital payment transactions for the last three years exhibited an escalating trend with $\mathrm{Rp}$ (Rp-Rupiah, Indonesian Currency. 1 USD = 14,197 Rp) 56 trillion in 2019, Rp 47 trillion in 2018, and Rp 12 trillion in 2017 [12]. E-money or e-wallet payments are the most popular form of fintech services in Indonesia, followed by web-based investment, and pay-later services. E-money transactions in Indonesian retail market rose by 173\% in January 2020 from the previous year due to the rapid adoption of a cashless environment. Astonishingly, e-money transactions hit Rp 15.8 trillion in January 2020 alone [2].

The largest digital transactions in Indonesia derive from retail (28\%), online transportation $(27 \%)$, food orders (20\%), e-commerce (15\%), and bill payments (7\%) [14]. Based on the world payment report published in 2019, the digital consumers in Indonesia grew from 64 million to 102 million between 2017 and 2018, which reflects almost half of the total population in Indonesia. The growing number of digital consumers has been projected to escalate online shopping transactions by 3.7-fold from USD 13.1 billion in 2017 to USD 48.3 billion in 2025. The top four e-wallet platforms in Indonesia based on the number of active users between 2017 and 2019 were Go-Pay, OVO, DANA, and Linkaja. The steady growth displayed by OVO is ascribed to its partnership with Grab, the Southeast Asia's largest ride hailing service, as well as Tokopedia, the dominant player in Indonesia's online e-commerce market. Next, DANA, which was introduced in 2018, had managed to boost its popularity and replaced Linkaja in third position in second quarter of 2019. Meanwhile, Linkaja already enjoys a convenient position as it has integrated payment services provided by state-owned banks-Telkomsel's T-Cash [12]. This showcases the huge potential 
possessed by Indonesia for using e-wallets as a smart way to make payments for local and international transactions in the future.

\section{Literature Review}

\subsection{Theoretical Foundation}

The theory of planned behavior by Ajzen [15] has been widely applied to explore individual adoption behavior of information systems. This theory upholds that intentions to perform behavior based on varied consumer stances may be accurately predicted using attitudes, social influence, and perceived behavioral control. This theory of planned behavior was extended to UTAUT by Venkatesh et al. [16] to specifically emphasize the critical factors and the contingencies in predicting intention behavior to use a technology primarily from the viewpoint of consumers. The four key constructs of UTAUT that influence one's behavioral intention to use a technology are: performance expectancy, effort expectancy, social influence, and facilitating conditions. Performance expectancy is defined as the degree to which using a technology will offer benefits to consumers in performing certain activities. Effort expectancy refers to the degree of ease associated with consumers' use of technology. Meanwhile, social influence denotes the extent to which consumers perceive that important people in their lives, such as family and friends, believe that they should use a particular technology. Lastly, facilitating conditions reflect consumers' perceptions of the resources and support available to perform the target behavior [16].

In light of UTAUT, performance expectancy, effort expectancy, and social influence have been theorized to influence behavioral intention to use a technology, while behavioral intention and facilitating conditions determine technology use. This theory incorporates individual difference characteristic, namely age, gender, and experience, to determine the decision making to adopt technology use. This theory has been deployed in many studies concerning consumer adoption of information and communication technology (ICT) in the Industrial Revolution 4.0 (IR 4.0), such as mobile phones, e-wallets, and internet banking [17], as well as virtual technology for online purchase intention [18]. In a similar vein, Lim et al. [19] stated that UTAUT offers an opportunity to identify the multiple factors that determine user acceptance of a new technology. As such, this present study had probed into several constructs of consumer intention to adopt e-wallet through the lens of UTAUT, so as to better comprehend consumer intention as a mediating variable of the adoption of e-wallets, as well as being moderated by age, gender, and education.

In the present era of IR 4.0, the emergence of the e-wallet as the preferred mode of payment in this digital century is bound to overtake cash spending in the near future. The digital market has rapidly turned into the mainstream mode of online payment due to convenience and ease of use [20]. Hence, e-wallet providers should understand the importance of gauging consumers' attitudes towards e-wallets in affecting behavioral outcomes, such as intention, retention, and loyalty to repurchase. Moreover, e-wallets offer an easy way to store e-money and to make payments for online purchases. Upon initiating the UTAUT, Venkatesh et al. [11] asserted that one's reaction towards using ICT can directly affect one's intention to use technology, which in turn can affect the actual use of IT. For instance, Shankar and Datta [21] proposed several antecedents to investigate the adoption of e-wallets, including perceived ease of use, perceived usefulness, perceived trust, social influence, and personal innovativeness. Chandra and Kumar [18], who explored the underlying factors that affected the intention among management students to use e-wallets, discovered that perceived usefulness, perceived ease of use, social influence, and trust propensity influenced behavioral intention to use mobile banking services. For effective adoption of e-wallets from the consumers' stance, e-commerce providers should consider both internal (e.g., perceived usefulness, perceived ease of use, and perceived trust) and external (e.g., social influence, facilitating condition, and lifestyle compatibility) factors to intensify consumers' intention [18]. As such, this present study examined perceived usefulness, perceived ease of use, social influence, facilitating condition, lifestyle 
compatibility, and perceived trust to determine consumers' intention to adopt an e-wallet, while being moderated by age, gender, and education.

\subsection{Factors Affecting Intention to Use e-Wallet}

\subsubsection{Perceived Usefulness}

Perceived usefulness (PU) refers to one's belief that using the system will improve job performance [22]. Essentially, it describes a user's cognitive expectation about the system performance. Hence, consumers believe that using such a system can fulfil their financial and lifestyle desires, besides increasing efficiency in the way they conduct various transactions. Moreover, PU has been proven to display a positive effect on the intention to use e-payment in uncertain conditions [23]. This usefulness may add other services to ensure consumers enjoy using e-wallets as an alternative payment, especially to curb the spread of COVID-19. Past studies have reported perceived usefulness as a strong predictor of consumer's behavior intention [24]. The digital infrastructure contributes to the information delivery system, thus enhancing the effect of the perceived usefulness of the system on intention to use the technology. As such, the following hypothesis is proposed:

Hypothesis 1 (H1). Perceived usefulness has a significantly positive effect on the intention to use e-wallets among adults.

\subsubsection{Perceived Ease of Use}

A major determinant of user attitude and behavior intention to accept and use a technology is perceived ease of use [25]. It was evidenced that perceived ease of use (PE) is vital in affecting consumers' intention to purchase. As a result, past purchase experience may affect a consumer's perceived ease of use regarding e-wallets. The experience of using the e-wallet app was reported as easy to use by many consumers [26]. Therefore, perceived ease of use reflects the ease of using a technology to access a website to purchase online [27]. The use of technology is more profitable for online users; in other words, easier application of a technology will make it the payment method of the choice for consumers to perform transactions. As such, the following hypothesis is proposed:

Hypothesis 2 (H2). Perceived ease of use has a significantly positive effect on the intention to use $e$-wallets among adults.

\subsubsection{Social Influence}

Social influence (SI) has been significantly constructed to assess consumers' desire to use mobile payment [28]. The potential influencers for consumers to use AEW are family members, friends, colleagues, and neighbors [29]. Hence, SI denotes the effect of environmental factors that encourage consumers to purchase or sell new products [11]. Similarly, Martins et al. [30] found that social influence had an impact on the intention of online users to adopt Internet services, while Chaouali et al. [31] reported that social influence affected the mindset of every individual on the use of new innovative products through technology services. Social influence (SI) can be derived from the effect of subjective norms and social factors on behavior intention to use e-money in UTAUT. Based on the above depiction, the following is hypothesized:

Hypothesis 3 (H3). Social influence has a significantly positive effect on the intention to use e-wallets among adults.

\subsubsection{Facilitating Conditions}

Facilitating conditions (FC) have been defined as the factors and the technical infrastructure that enhance mobile banking, such as training on how to use mobile banking or the capability and resources of a consumer [25]. Hossain et al. [32] noted that facilitating conditions displayed a significantly positive impact on consumers' intention to purchase a product. After enjoying the convenience of using the facilities provided by service providers that ease payments and transactions, consumers are bound to continue using the 
services. Tarhini et al. [33] claimed that facilitating conditions enable users to creatively use the e-learning system so that the users become smart and always upgrade new menus in the app. In addition, Peñarroja et al. [34] confirmed that facilitating conditions positively influenced the knowledge-sharing behavior of using technology during this digital era. These findings point out that consumers often participate in virtual communities when facilitating conditions exist. As such, this study proposes the following hypothesis:

Hypothesis $4 \mathbf{( H 4 ) . ~ F a c i l i t a t i n g ~ c o n d i t i o n s ~ h a v e ~ a ~ s i g n i f i c a n t l y ~ p o s i t i v e ~ e f f e c t ~ o n ~ t h e ~ i n t e n t i o n ~ t o ~}$ use e-wallets among adults.

\subsubsection{Lifestyle Compatibility}

Lifestyle compatibility (LC) is defined as the natural alignment of lifestyle choices and value [25]. This aspect of lifestyle compatibility is important to reduce the potential uncertainty of using technology in relation to a user's value, experiences, lifestyle, and preferences [35]. Accordingly, lifestyle compatibility influences one's behavior and offers great benefits in estimating consumers' behavioral intention [36]. Similarly, Herrero et al. [37] depicted that lifestyle compatibility with technology, which is related to prior experience and value, displayed a direct impact on the adoption of an e-wallet. If consumers are accustomed to interacting with apps, they will probably assume that technology offers them convenience to purchase a product. As such, the following hypothesis is proposed:

Hypothesis 5 (H5). Lifestyle compatibility has a significantly positive effect on the intention to use e-wallets among adults.

\subsubsection{Perceived Trust}

As consumers begin trusting a system or a service provider, they will continually use the application to purchase products. Hoque and Alam [38] asserted that knowledge induces the level of trust in the information source. Hence, identifying the opportunity to leverage the existing knowledge of the consumer to build trust can intensify the consumer's purchase intention. Thus, trust in the information source can significantly affect purchase intention. Sullivan and Kim [39] noted that repurchase intention in e-commerce may be increased by increasing trust through low perceived risk that consumers gain from online system. According to Kim et al. [40], perceived trust (PT) has a crucial role in predicting one's purchase intention by reducing perceived risk during the transaction. Therefore, perceived trust towards a mobile payment system is a vital factor in increasing business profits [41]. Based on the empirical studies above, this study proposes the following hypothesis:

Hypothesis 6 (H6). Perceived trust has a significantly positive effect on the intention to use e-wallets among adults.

\subsubsection{Intention to Use an e-Wallet}

The UTAUT, an extension of the Theory of Reasoned Action, is a key model to understand the predictors of human behavior towards potential acceptance or rejection of technology [42]. According to Fishbein and Ajzen [43], intention to use an e-wallet is the measure of the intensity of one's intention to purchase a product. Some factors used to describe intention to use e-wallet, such as perceived of usefulness, perceived ease of use, perceived risk, social influence, price, trust, and the like, have been applied to measure behavior intention towards the adoption of technology [19]. Moreover, Nikou and Economides [44], who investigated cognitive feedback and user interface to predict the relationship between behavior intention to use an e-wallet, discovered the positive effect of behavior intention on adoption of an e-wallet. Based on the depiction above, this study proposes the following:

Hypothesis 7 (H7). Intention to use an e-wallet has a significantly positive effect on the adoption of e-wallets among adults. 


\subsection{Mediating Effect of Intention to Use e-Wallet}

Consumers' behavior can be shaped as long as social influence can influence one's intention. Upon exploring the effect of the perceived ease of use on consumer adoption. Choi and Sun [45] reported that if consumers can rapidly grab and hold the flow of the application, it can lead to high perceived ease of use. This can further improve usability, minimize errors, and attract more people to adopt the service. Xie and Lin [46] found that perceived ease of use was mediated by intention to use an e-wallet towards consumer adoption. Another study discovered that the effect of facilitation conditions was mediated by behavior intention towards consumer adoption [11]. Consumers can benefit from the adoption of an e-wallet when they receive a greater return from using the technology. Thus, the following is hypothesized:

Hypothesis 8 (H8). The effects of e-wallets' perceived usefulness, perceived ease of use, social influence, facilitating condition, lifestyle compatibility, and perceived trust on adoption of e-wallets among adults were mediated by the intention to use an $e$-wallet.

\subsection{Moderating Effect of Age, Gender and Education}

The amount of studies examining the role of age in consumer behavior has increased substantially [47]. These authors reported that age and gender emerged as crucial factors in use, including a reduction in menu complexity, better resolution, and a larger screen. Age and gender, are one's internal aspects that explain consumer behavior regarding using technology, along with having a significant impact on the adoption of digital devices. Gender is a key factor for product evaluation that affects the decision-making process [9]. Clearly, gender can change the alternatives of using certain platforms, apps, and technologies [9]. Meanwhile, education has been reported as a better predictor of the young generation using technology and is strongly related to both motivation and capability to adapt to innovations [48]. The education factor is integral to bridge the gender gap in the attitudes towards technology use [49]. Therefore, understanding the differences in terms of age, gender, and education is denoted as a strategy to market products and to satisfy the needs of consumers. Hence, the following hypothesis is proposed:

Hypothesis 9 (H9). Age moderates the relationships of perceived usefulness, perceived ease of use, social influence, facilitating conditions, lifestyle compatibility, and perceived trust with the intention to use e-wallets among adults.

Hypothesis 10 (H10). Gender moderates the relationships of perceived usefulness, perceived ease of use, social influence, facilitating conditions, lifestyle compatibility, and perceived trust with the intention to use e-wallets among adults.

Hypothesis 11 (H11). Level of education moderates the relationships of perceived usefulness, perceived ease of use, social influence, facilitating conditions, lifestyle compatibility, and perceived trust with the intention to use e-wallets among adults.

Figure 1 illustrates all of the hypothesized and tested associations in this study. 


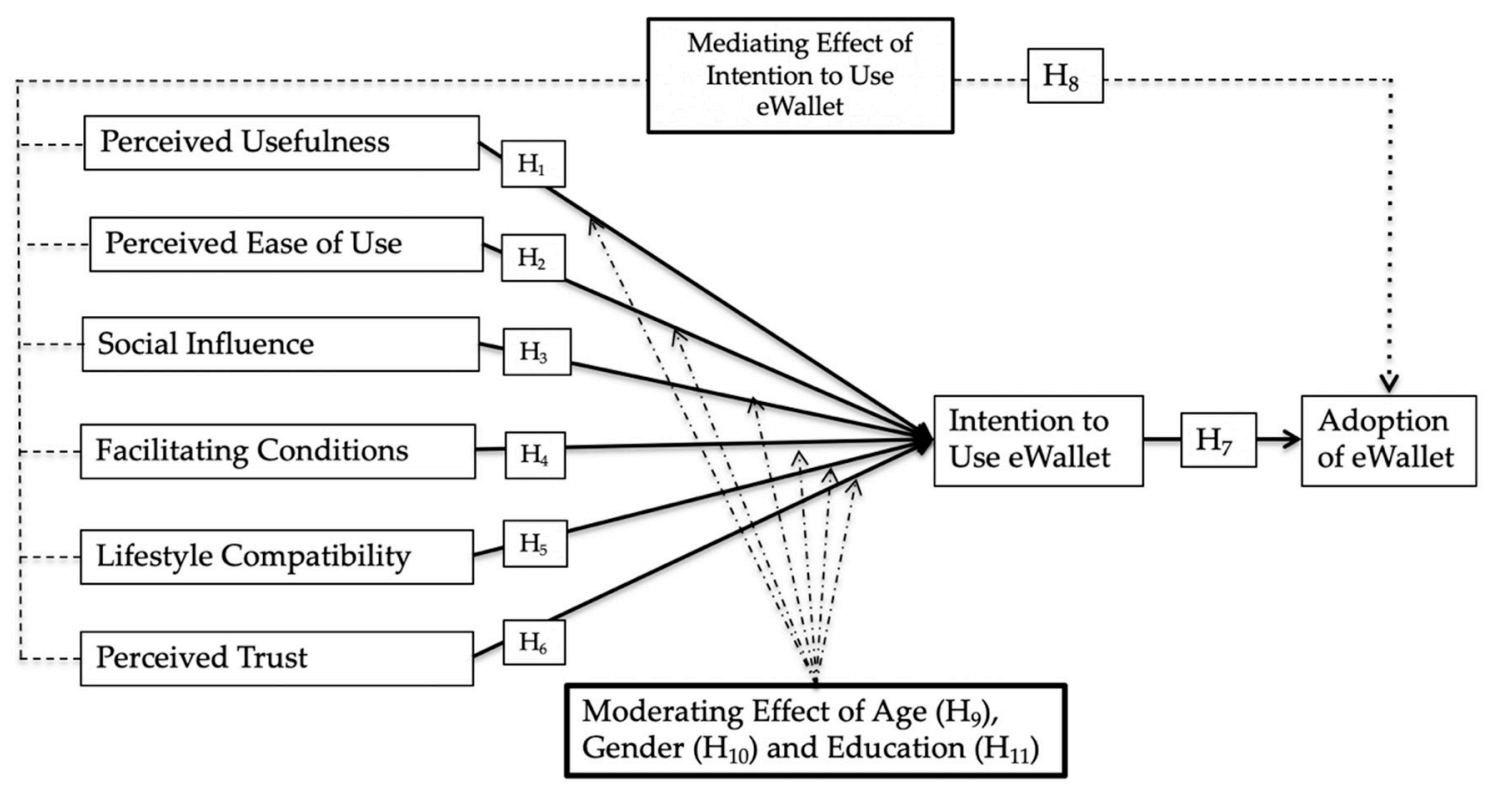

Figure 1. Research framework.

\section{Research Methodology}

\subsection{Data Collection and Sample Design}

A Google Form survey was used for data collection in this study. The questionnaire was disseminated from April to July 2020 to consumers in Indonesia who had used an e-wallet to perform transactions. As a result, 501 responses to the questionnaire were eligible for statistical analysis. The Google Form is a method of convenience sampling to execute data collection. Additionally, structural interviews were carried out with several respondents to capture more information regarding the benefits of using an e-wallet. Each questionnaire item was first translated into the Indonesian language by the author and later was translated into the English language to assure consistency. Complete data presented in this study are available in the Supplementary Material (Data File-Cashless Transection.csv).

\subsection{Measurement and Scales}

All the scales items for this study were derived from previously validated instruments. Five items for PU were adopted from Lwoga and Lwoga [22], while six items for PE were retrieved from Chawla and Joshi [25]. Next, five items each for SI and LC were obtained from Lwoga and Lwoga [22], whereas five items for FC were retrieved from Pandey and Chawla [50]. Six items each for PT and intention to use an e-wallet (IEW) were taken from Chawla and Joshi [25] and Karjaluoto et al. [51], respectively. Lastly, the two items for AEW were adapted from Karjaluoto et al. [51].

\subsection{Data Analysis Method}

The partial least square structural equation modelling (PLS-SEM) was employed to estimate complex cause-effect relationship models with latent variables [52]. Contrasting covariance-based approaches to structural equation modelling are suitable to assess higherorder constructs and complex conceptual model with mediation effects [53]. Since the study sample exceeded $100(n=501)$, the PLS-SEM technique via Smart-PLS was suitable for this study to test the causal-effect relationships proposed in this study model. 


\section{Data Analysis}

\subsection{Demographic Characteristics}

Table 1 shows the demographic profiles of the respondents in this study. Apparently, more of the respondents were female $(56.9 \%)$ than male $(43.1 \%)$. A majority of the respondents were $20-29$ years old $(61.3 \%)$, while $25.7 \%$ were below 20 years old, $6.8 \%$ were above 40 years of age, and $6.2 \%$ were $30-39$ years old. Most of the respondents possessed a bachelor's degree (52.5\%), while $33.3 \%$ were high school graduates, $10.2 \%$ held a master's degree, and $1.8 \%$ had earned a diploma. In total, $66.3 \%$ of the respondents were students, whereas the remaining $33.7 \%$ were employees.

Table 1. Demographic characteristics.

\begin{tabular}{lcc}
\hline & $\mathbf{N}$ & $\%$ \\
\hline Gender & 285 & \\
Female & 216 & 56.9 \\
Male & 501 & 43.1 \\
Total & & 100 \\
\hline Age Group & 129 & \\
Below 20 years & 307 & 25.7 \\
20-29 years & 31 & 61.3 \\
30-39 years & 34 & 6.2 \\
40 and above & 501 & 6.8 \\
Total & & 100 \\
\hline Education & 167 & 33.3 \\
High school & 9 & 1.8 \\
Diploma & 263 & 52.5 \\
Bachelor & 51 & 10.2 \\
Master & 501 & 100 \\
Total & & \\
\hline Employment Status & 332 & 66.3 \\
Student & 169 & 33.7 \\
Worker & 501 & 100.0 \\
Total & & \\
\hline
\end{tabular}

\subsection{Validity and Reliability}

The first step in SEM is to assess the measurement model, which includes the evaluation of construct reliability, indicator reliability, convergent validity, and discriminant validity of the outlined constructs. Construct reliability was determined using composite reliability (CR) and Cronbach's alpha (CA). The criterion is that the $\mathrm{CR}$ value should exceed 0.07 to indicate adequate reliability of the construct [54]. The measurement model results, as tabulated in Table 2, showed that the CR values obtained for this present were greater than 0.07 , thus confirming adequate construct reliability. Next, indicator reliability was assessed through $\mathrm{CA}$, in which the CA values must be higher than 0.06 . As a result, the CA for all factors in this study was acceptable. Convergent validity of constructs was determined using average variance extracted (AVE), which should exceed 0.50 [55]. Since the result revealed that all constructs had substantial AVE, the convergent validity of constructs for this study was verified. The values of CA, CR, and AVE are depicted in Table 2. 
Table 2. Reliability and validity.

\begin{tabular}{ccccccccc}
\hline Variables & $\begin{array}{c}\text { No. } \\
\text { Items }\end{array}$ & Mean & SD & CA & DG rho & CR & AVE & VIF \\
\hline PU & 5 & 4.164 & 0.643 & 0.834 & 0.835 & 0.883 & 0.603 & 2.819 \\
PE & 6 & 4.045 & 0.628 & 0.859 & 0.893 & 0.901 & 0.620 & 2.754 \\
SI & 5 & 3.854 & 0.676 & 0.788 & 0.790 & 0.855 & 0.543 & 3.210 \\
FC & 5 & 3.670 & 0.756 & 0.839 & 0.842 & 0.886 & 0.609 & 3.492 \\
LM & 4 & 3.854 & 0.754 & 0.866 & 0.868 & 0.909 & 0.714 & 4.002 \\
PT & 6 & 4.013 & 0.705 & 0.896 & 0.897 & 0.920 & 0.659 & 3.188 \\
IEW & 6 & 4.008 & 0.658 & 0.887 & 0.889 & 0.914 & 0.641 & 1.000 \\
AEW & 5 & 3.727 & 0.786 & 0.841 & 0.856 & 0.887 & 0.614 & \\
\hline
\end{tabular}

Note: PU: perceived usefulness; PE: perceived ease of use; SI: social influence; FC: facilitating conditions; LM: lifestyle compatibility; PT: perceived trust; IEW: intention to use an e-wallet; AEW: adoption of an e-wallet; SD: standard deviation; CA: Cronbach's alpha; DG rho: Dillon-Goldstein's rho; CR: composite reliability; AVE: average variance extracted; VIF: Variance Inflation Factors. Source: Author's data analysis

The assessment of the measurement model included the evaluation of discriminant validity of the constructs based on three methods: Fornell and Lacker criterion, crossloading, and Heterotrait-Monotrait ratio (HTMT) [54]. The Fornell-Lacker criterion is used to assess the discriminant validity by comparing the square root of AVE extracted from each construct with the correlation among constructs. Next, the cross-loading method suggests that the outer loading of the construct should exceed the corresponding construct loading to signify adequate discriminant validity of the construct. Lastly, the HTMT method estimates the discriminant validity of the construct based on multitrait and multimethod matrices. The results of Fornell-Lacker and HTMT are presented in Table 3, while the outcomes of cross-loading are given in Table 4. According to Kline et al. [56], values above 0.85 indicate adequate discriminant validity of the measurement. Therefore, this study confirmed the discriminant validity of the constructs as all loadings of the constructs were higher than the other constructs. Finally, discriminant validity is checked with the Fornell-Lacker criterion, which revealed strong links among the constructs.

Table 3. Discriminant validity.

\begin{tabular}{|c|c|c|c|c|c|c|c|c|}
\hline & PU & PE & SI & FC & LM & PT & IEW & AEW \\
\hline \multicolumn{9}{|l|}{ Fornell-Larcker Criterion } \\
\hline Perceived Usefulness & 0.776 & & & & & & & \\
\hline Perceived Ease of Use & 0.721 & 0.787 & & & & & & \\
\hline Social Influence & 0.659 & 0.639 & 0.737 & & & & & \\
\hline Facilitating Conditions & 0.617 & 0.651 & 0.736 & 0.780 & & & & \\
\hline Compatibility & 0.636 & 0.652 & 0.696 & 0.781 & 0.845 & & & \\
\hline Perceived Trust & 0.624 & 0.618 & 0.686 & 0.646 & 0.766 & 0.812 & & \\
\hline Intention to Use e-Wallet & 0.651 & 0.650 & 0.689 & 0.676 & 0.764 & 0.766 & 0.801 & \\
\hline Adoption of e-Wallet & 0.586 & 0.536 & 0.620 & 0.645 & 0.680 & 0.651 & 0.742 & 0.784 \\
\hline \multicolumn{9}{|c|}{ Heterotrait-Monotrait Ratio (HTMT) } \\
\hline Perceived Usefulness & - & & & & & & & \\
\hline Perceived Ease of Use & 0.854 & - & & & & & & \\
\hline Social Influence & 0.814 & 0.804 & - & & & & & \\
\hline Facilitating Conditions & 0.732 & 0.771 & 0.909 & - & & & & \\
\hline Compatibility & 0.748 & 0.762 & 0.843 & 0.912 & - & & & \\
\hline Perceived Trust & 0.716 & 0.709 & 0.812 & 0.735 & 0.864 & - & & \\
\hline Intention to Use e-Wallet & 0.758 & 0.752 & 0.825 & 0.782 & 0.872 & 0.859 & - & \\
\hline Adoption of e-Wallet & 0.692 & 0.625 & 0.760 & 0.763 & 0.791 & 0.740 & 0.849 & - \\
\hline
\end{tabular}

Note: PU: perceived usefulness; PE: perceived ease of use; SI: social influence; FC: facilitating conditions; LM: lifestyle compatibility; PT: perceived trust; IEW: intention to use an e-wallet; AEW: adoption of an e-wallet. Source: Author's data analysis. 
Table 4. Loadings and cross-loading.

\begin{tabular}{|c|c|c|c|c|c|c|c|c|}
\hline & PU & PE & SI & FC & LM & PT & IEW & AEW \\
\hline $\begin{array}{l}\text { Using an e-wallet makes it easier for me } \\
\text { to conduct my daily transactions }\end{array}$ & 0.801 & 0.608 & 0.498 & 0.522 & 0.493 & 0.478 & 0.523 & 0.441 \\
\hline $\begin{array}{l}\text { Using an e-wallet allows me to manage } \\
\text { my transactions more efficiently }\end{array}$ & 0.808 & 0.560 & 0.500 & 0.493 & 0.499 & 0.469 & 0.502 & 0.466 \\
\hline $\begin{array}{l}\text { Using an e-wallet increases my } \\
\text { productivity }\end{array}$ & 0.777 & 0.519 & 0.523 & 0.521 & 0.541 & 0.511 & 0.513 & 0.509 \\
\hline $\begin{array}{l}\text { Using an e-wallet enables me to } \\
\text { accomplish tasks e.g., payments more } \\
\text { quickly }\end{array}$ & 0.784 & 0.604 & 0.516 & 0.432 & 0.472 & 0.514 & 0.495 & 0.392 \\
\hline $\begin{array}{l}\text { Overall, I believe an e-wallet is more } \\
\text { useful than traditional ways of conduct } \\
\text { transactions }\end{array}$ & 0.707 & 0.504 & 0.519 & 0.421 & 0.462 & 0.447 & 0.490 & 0.463 \\
\hline $\begin{array}{l}\text { Learning how to use an e-Wallet is easy } \\
\text { for me }\end{array}$ & 0.611 & 0.863 & 0.483 & 0.529 & 0.555 & 0.474 & 0.536 & 0.406 \\
\hline $\begin{array}{l}\text { My interaction with an e-Wallet is clear } \\
\text { and understandable }\end{array}$ & 0.641 & 0.797 & 0.535 & 0.537 & 0.534 & 0.556 & 0.548 & 0.467 \\
\hline I find an e-wallet easy to use & 0.615 & 0.862 & 0.518 & 0.519 & 0.541 & 0.518 & 0.541 & 0.435 \\
\hline $\begin{array}{l}\text { It is easy for me to become skillful at } \\
\text { using an e-wallet }\end{array}$ & 0.285 & 0.319 & 0.425 & 0.307 & 0.279 & 0.308 & 0.279 & 0.249 \\
\hline $\begin{array}{l}\text { It is easy for me to remember how to } \\
\text { perform task with an e-wallet }\end{array}$ & 0.607 & 0.880 & 0.515 & 0.550 & 0.532 & 0.491 & 0.550 & 0.472 \\
\hline $\begin{array}{l}\text { I like the fact that payments done } \\
\text { through an e-wallet require minimum } \\
\text { effort }\end{array}$ & 0.561 & 0.848 & 0.551 & 0.582 & 0.574 & 0.528 & 0.551 & 0.457 \\
\hline $\begin{array}{l}\text { People who influence my behavior think } \\
\text { that I should use an e-wallet }\end{array}$ & 0.558 & 0.629 & 0.661 & 0.505 & 0.501 & 0.490 & 0.488 & 0.405 \\
\hline $\begin{array}{l}\text { People who are important to me think } \\
\text { that I should use an e-wallet }\end{array}$ & 0.482 & 0.419 & 0.800 & 0.524 & 0.532 & 0.503 & 0.515 & 0.506 \\
\hline $\begin{array}{l}\text { e-wallets are widely used by people in } \\
\text { my community }\end{array}$ & 0.484 & 0.370 & 0.782 & 0.528 & 0.523 & 0.524 & 0.529 & 0.494 \\
\hline Almost all my friends use e-wallets & 0.471 & 0.501 & 0.719 & 0.540 & 0.519 & 0.546 & 0.541 & 0.427 \\
\hline My family members use e-wallets & 0.429 & 0.441 & 0.715 & 0.623 & 0.482 & 0.454 & 0.457 & 0.447 \\
\hline $\begin{array}{l}\text { I am given the necessary support and } \\
\text { assistance to use an e-wallet }\end{array}$ & 0.408 & 0.432 & 0.546 & 0.750 & 0.481 & 0.414 & 0.454 & 0.461 \\
\hline $\begin{array}{l}\text { I have the financial and technological } \\
\text { resources required to use an e-wallet }\end{array}$ & 0.478 & 0.424 & 0.625 & 0.761 & 0.564 & 0.448 & 0.520 & 0.524 \\
\hline $\begin{array}{l}\text { I have access to the software and } \\
\text { hardware required to use an e-wallet }\end{array}$ & 0.544 & 0.577 & 0.557 & 0.837 & 0.641 & 0.539 & 0.564 & 0.533 \\
\hline $\begin{array}{l}\text { The e-wallet services I use are well } \\
\text { integrated and provided in a stable } \\
\text { service infrastructure }\end{array}$ & 0.453 & 0.537 & 0.534 & 0.786 & 0.643 & 0.472 & 0.525 & 0.500 \\
\hline $\begin{array}{l}\text { My service provider/operator facilitates } \\
\text { the use of an e-wallet }\end{array}$ & 0.509 & 0.555 & 0.608 & 0.762 & 0.696 & 0.625 & 0.562 & 0.493 \\
\hline $\begin{array}{l}\text { Using e-wallet services is compatible } \\
\text { with all aspects of my lifestyle }\end{array}$ & 0.492 & 0.539 & 0.566 & 0.715 & 0.792 & 0.594 & 0.624 & 0.521 \\
\hline $\begin{array}{l}\text { Using e-wallet services fits into my } \\
\text { lifestyle }\end{array}$ & 0.525 & 0.540 & 0.615 & 0.655 & 0.843 & 0.661 & 0.607 & 0.565 \\
\hline $\begin{array}{l}\text { Using e-wallet services fits well with the } \\
\text { way I like to purchase products and } \\
\text { services }\end{array}$ & 0.507 & 0.528 & 0.570 & 0.638 & 0.876 & 0.631 & 0.672 & 0.618 \\
\hline $\begin{array}{l}\text { Using e-wallets is completely compatible } \\
\text { with my current situation }\end{array}$ & 0.623 & 0.597 & 0.601 & 0.638 & 0.866 & 0.698 & 0.673 & 0.590 \\
\hline
\end{tabular}


Table 4. Cont.

\begin{tabular}{|c|c|c|c|c|c|c|c|c|}
\hline & PU & PE & SI & FC & $\mathbf{L M}$ & PT & IEW & AEW \\
\hline $\begin{array}{l}\text { I trust that a transaction conducted } \\
\text { through an e-wallet is secure and private }\end{array}$ & 0.599 & 0.556 & 0.544 & 0.546 & 0.701 & 0.726 & 0.642 & 0.548 \\
\hline $\begin{array}{l}\text { I trust payments made through e-wallet } \\
\text { channels will be processed securely }\end{array}$ & 0.412 & 0.436 & 0.529 & 0.473 & 0.557 & 0.809 & 0.559 & 0.513 \\
\hline $\begin{array}{l}\text { I believe my personal information on an } \\
\text { e-wallet will be kept confidential }\end{array}$ & 0.512 & 0.528 & 0.566 & 0.501 & 0.610 & 0.880 & 0.625 & 0.552 \\
\hline $\begin{array}{l}\text { I believe e-wallet providers keeps } \\
\text { customers' best interests in mind }\end{array}$ & 0.426 & 0.417 & 0.514 & 0.464 & 0.529 & 0.821 & 0.573 & 0.473 \\
\hline $\begin{array}{l}\text { I believe that in case of any issue, the } \\
\text { e-wallet service provider will provide me } \\
\text { assistance }\end{array}$ & 0.528 & 0.518 & 0.609 & 0.577 & 0.655 & 0.816 & 0.634 & 0.497 \\
\hline $\begin{array}{l}\text { I believe that the e-wallet service } \\
\text { providers follow consumer laws }\end{array}$ & 0.534 & 0.530 & 0.565 & 0.566 & 0.650 & 0.812 & 0.677 & 0.570 \\
\hline $\begin{array}{l}\text { Assuming that I have access to e-wallet, I } \\
\text { intend to use it }\end{array}$ & 0.502 & 0.520 & 0.572 & 0.540 & 0.573 & 0.741 & 0.708 & 0.502 \\
\hline $\begin{array}{l}\text { I intend to use an e-wallet if the cost and } \\
\text { times is reasonable for me }\end{array}$ & 0.492 & 0.472 & 0.537 & 0.502 & 0.589 & 0.609 & 0.797 & 0.588 \\
\hline I intend to use an e-wallet in the future & 0.521 & 0.530 & 0.525 & 0.543 & 0.586 & 0.583 & 0.742 & 0.504 \\
\hline $\begin{array}{l}\text { I intend to increase my use of e-wallets in } \\
\text { the future }\end{array}$ & 0.517 & 0.544 & 0.573 & 0.585 & 0.652 & 0.593 & 0.841 & 0.647 \\
\hline $\begin{array}{l}\text { I intend to continue using an e-wallet } \\
\text { more frequently in the future }\end{array}$ & 0.557 & 0.528 & 0.569 & 0.527 & 0.611 & 0.580 & 0.863 & 0.654 \\
\hline I intend to use an e-wallet in my daily life & 0.535 & 0.530 & 0.535 & 0.550 & 0.653 & 0.583 & 0.842 & 0.655 \\
\hline $\begin{array}{l}\text { I often use an e-wallet to manage my } \\
\text { account. }\end{array}$ & 0.433 & 0.434 & 0.467 & 0.512 & 0.554 & 0.514 & 0.643 & 0.817 \\
\hline $\begin{array}{l}\text { I often use an e-wallet to transfer and } \\
\text { remit money. }\end{array}$ & 0.456 & 0.395 & 0.527 & 0.521 & 0.557 & 0.552 & 0.615 & 0.821 \\
\hline I often use an e-wallet to make payments. & 0.548 & 0.458 & 0.512 & 0.532 & 0.531 & 0.536 & 0.591 & 0.820 \\
\hline $\begin{array}{l}\text { I subscribe to financial products that are } \\
\text { exclusive to mobile banking. }\end{array}$ & 0.526 & 0.542 & 0.522 & 0.561 & 0.597 & 0.558 & 0.617 & 0.811 \\
\hline $\begin{array}{l}\text { On average, how often have you used an } \\
\text { e-wallet per month? (Never, } 1 \text { to } 5 \text { times; } 6 \\
\text { to } 10 \text { times; } 11 \text { to } 15 \text { times; More than } \\
15 \text { times) }\end{array}$ & 0.303 & 0.225 & 0.390 & 0.382 & 0.399 & 0.360 & 0.405 & 0.631 \\
\hline
\end{tabular}

Note: PU: perceived usefulness; PE: perceived ease of use; SI: social influence; FC: facilitating conditions; LM: lifestyle compatibility; PT: perceived trust; IEW: intention to use an e-wallet; AEW: adoption of an e-wallet. The Italic values in the matrix above are the item loadings, and others are cross-loadings. Source: Author's data analysis.

\subsection{Path Analysis}

The structural model results shown in Table 5 reveal that the causal relationship between perceived usefulness and intention to use e-wallet was statically significant, while the relationship between perceived ease of use and intention to use an e-wallet was also significant. Next, social influence, lifestyle compatibility, and perceived trust exhibited a significant effect on the intention to use an e-wallet. On the contrary, the link between facilitating condition and intention to use e-wallet was not significant.

Next, effect size $\left(\mathrm{f}^{2}\right)$ results of effect size for this study are tabulated in Table 5 . The $\mathrm{f}^{2}$ score, which ranged from 0.000 to 0.132 , showed that all constructs in this study had a small effect size on the consumers' intention to use an e-wallet. According to Hair et al. [54], the blindfolding procedure shows how construct values are well-observed by reconstructing the parameter estimates. The blindfolding procedure was applied only on endogenous constructs with reflective indicators. Predictive relevance of the model was calculated collectively with $\mathrm{Q}^{2}$, including all factors and at the individual level (single factor). Table 5 presents the results of predictive relevance $Q^{2}$. The results of the blindfolding procedure show that the predictive relevance of the model was substantial at $0.451 \%$, thus verifying the integration of predictors towards the adoption of an e-wallet. This signified that the 
consumers' intention to adopt an e-wallet was substantial. In addition, all the exogenous variables displayed substantial levels of predictive relevance with their respective endogenous variables.

Table 5. Path coefficients.

\begin{tabular}{|c|c|c|c|c|c|c|c|c|c|c|}
\hline Hypo & & Beta & $\begin{array}{l}\text { CI- } \\
\text { Min }\end{array}$ & $\begin{array}{l}\text { CI- } \\
\text { Max }\end{array}$ & $\mathbf{t}$ & $\mathbf{p}$ & $\mathbf{r}^{2}$ & $\mathbf{f}^{2}$ & $Q^{2}$ & Decision \\
\hline \multicolumn{11}{|c|}{ Factors affecting Intention to Use e-Wallet } \\
\hline $\mathrm{H}_{1}$ & PU $\Rightarrow$ IEW & 0.108 & 0.033 & 0.175 & 2.566 & 0.005 & \multirow{6}{*}{0.726} & 0.132 & \multirow{6}{*}{0.451} & Accept \\
\hline $\mathrm{H}_{2}$ & $\mathrm{PE} \Rightarrow \mathrm{IEW}$ & 0.099 & 0.027 & 0.173 & 2.237 & 0.013 & & 0.000 & & Accept \\
\hline $\mathrm{H}_{3}$ & $\mathrm{SI} \rightarrow \mathrm{IEW}$ & 0.110 & 0.024 & 0.195 & 2.075 & 0.019 & & 0.014 & & Accept \\
\hline $\mathrm{H}_{4}$ & $\mathrm{FC} \Rightarrow \mathrm{IEW}$ & 0.048 & -0.037 & 0.137 & 0.916 & 0.180 & & 0.002 & & Reject \\
\hline $\mathrm{H}_{5}$ & $\mathrm{LM} \Rightarrow \mathrm{IEW}$ & 0.265 & 0.178 & 0.358 & 4.875 & 0.000 & & 0.005 & & Accept \\
\hline $\mathrm{H}_{6}$ & $\mathrm{PT} \rightarrow \mathrm{IEW}$ & 0.339 & 0.255 & 0.416 & 6.979 & 0.000 & & 0.013 & & Accept \\
\hline \multicolumn{11}{|c|}{ Factor affecting adoption of e-Wallet } \\
\hline $\mathrm{H}_{7}$ & $\mathrm{IEW} \rightarrow \mathrm{AEW}$ & 0.742 & 0.701 & 0.783 & 28.780 & 0.000 & 0.551 & 0.005 & 0.330 & Accept \\
\hline
\end{tabular}

Note: PU: perceived usefulness; PE: perceived ease of use; SI: social influence; FC: facilitating conditions; LM: lifestyle compatibility; PT: perceived trust; IEW: intention to use an e-wallet; AEW: adoption of an e-wallet. Source: Author's data analysis.

\subsection{Mediation}

In this study, intention to use an e-wallet displayed a mediating effect on the relationship between perceived usefulness and the adoption of an e-wallet; the coefficient of perceived usefulness toward the adoption of an e-wallet was 0.066 , with a $p$-value $=0.000$. Next, regarding the mediating effect of the intention to use an e-wallet on the association between perceived ease of use and adoption of e-wallet, the coefficient of perceived ease of use on adoption of an e-wallet was 0.076 with a $p$-value $=0.000$. Moving on, the relationship between the social influence and the adoption of an e-wallet was mediated by the intention to use an e-wallet, the coefficient of social influence toward the adoption of an e-wallet was -0.020 , with a $p$-value $=0.049$. The intention to use an e-wallet was found to mediate the relationship between facilitating conditions and the adoption of an e-wallet; the coefficient of facilitating conditions toward the adoption of an e-wallet was 0.059 , with a $p$-value $=0.000$. The results reveal that the intention to use an e-wallet mediated the relationship between lifestyle compatibility and the adoption of an e-wallet; the coefficient of lifestyle compatibility toward the adoption of an e-wallet was 0.153 , with a $p$-value $=0.000$. Lastly, hypothesis 8 is supported due to the outcome that displayed the mediating effect of the intention to use an e-wallet on the relationship between perceived trust and the adoption of an e-wallet; the coefficient of perceived trust toward the adoption of an e-wallet was 0.086 with a $p$-value $=0.000$. The mediation results are presented in Table 6 .

Table 6. Mediating effect.

\begin{tabular}{|c|c|c|c|c|c|c|}
\hline & Beta & CI-Min & CI-Max & $T$ & $p$ & Decision \\
\hline $\mathrm{PU} \Rightarrow \mathrm{IEW} \Rightarrow \mathrm{AEW}$ & 0.080 & 0.024 & 0.134 & 2.503 & 0.006 & Accept \\
\hline $\mathrm{PE} \Rightarrow \mathrm{IEW} \rightarrow \mathrm{AEW}$ & 0.073 & 0.021 & 0.128 & 2.225 & 0.013 & Accept \\
\hline $\mathrm{SI} \Rightarrow \mathrm{IEW} \Rightarrow \mathrm{AEW}$ & 0.082 & 0.018 & 0.144 & 2.073 & 0.019 & Accept \\
\hline $\mathrm{FC} \Rightarrow \mathrm{IEW} \Rightarrow \mathrm{AEW}$ & 0.035 & -0.028 & 0.103 & 0.912 & 0.181 & Reject \\
\hline $\mathrm{LM} \Rightarrow \mathrm{IEW} \Rightarrow \mathrm{AEW}$ & 0.197 & 0.133 & 0.268 & 4.843 & 0.000 & Accept \\
\hline $\mathrm{PT} \Rightarrow \mathrm{IEW} \rightarrow \mathrm{AEW}$ & 0.252 & 0.188 & 0.313 & 6.762 & 0.000 & Accept \\
\hline
\end{tabular}

Note: PU: perceived usefulness; PE: perceived ease of use; SI: social influence; FC: facilitating conditions; LM: lifestyle compatibility; PT: perceived trust; IEW: intention to use an e-wallet; AEW: adoption of an e-wallet. Source: Author's data analysis. 


\subsection{Moderation}

The moderation effect of age, gender, and education was assessed on the relationships of perceived usefulness, perceived ease of use, social influence, facilitating condition, lifestyle compatibility, and perceived trust with the intention to use an e-wallet. As a result, the age factor failed to moderate the relationships between perceived usefulness, perceived ease of use, social influence, facilitating condition, and perceived trust and the intention to use an e-wallet. Nonetheless, a moderating effect was noted on the relationship between lifestyle compatibility and intention to use an e-wallet with $p=0.004$.

Similarly, gender did not moderate the relationships of social influence, facilitating condition and perceived trust with the adoption of an e-wallet. As a result, the gender factor failed to moderate the relationships between social influence and facilitating condition and perceived trust and the intention to use an e-wallet. On the contrary, gender displayed a moderating effect on the relationships of perceived usefulness and lifestyle compatibility with the intention to use an e-wallet. Regarding the relationship between perceived usefulness and the intention to use an e-wallet, the coefficient of perceived usefulness toward the intention to use an e-wallet was -0.067 with a $p$-value $=0.023$. In regard to the relationship between lifestyle compatibility and the intention to use an e-wallet, the coefficient of lifestyle compatibility toward the intention to use an e-wallet was -0.082 with a $p$-value $=0.019$. The factor of education also did not exhibit any moderating impact on the correlations of predictors toward the intention to use an e-wallet. The moderation results are presented in Table 7.

Table 7. Moderating effects.

\begin{tabular}{|c|c|c|c|c|c|c|}
\hline & Beta & CI-Min & CI-Max & $t$ & $p$ & Decision \\
\hline \multicolumn{7}{|c|}{ Moderating Effect of Age } \\
\hline $\mathrm{PU} \rightarrow \mathrm{IEW}$ & $(0.050)$ & $(0.107)$ & 0.004 & 1.550 & 0.061 & No Moderation \\
\hline $\mathrm{PE} \Rightarrow \mathrm{IEW}$ & $(0.051)$ & $(0.110)$ & 0.003 & 1.526 & 0.064 & No Moderation \\
\hline $\mathrm{SI} \Rightarrow \mathrm{IEW}$ & $(0.055)$ & $(0.112)$ & 0.015 & 1.414 & 0.079 & No Moderation \\
\hline $\mathrm{FC} \Rightarrow \mathrm{IEW}$ & 0.005 & $(0.064)$ & 0.070 & 0.125 & 0.450 & No Moderation \\
\hline $\mathrm{LM} \Rightarrow \mathrm{IEW}$ & 0.125 & 0.047 & 0.202 & 2.653 & 0.004 & Moderation \\
\hline $\mathrm{PT} \Rightarrow \mathrm{IEW}$ & 0.033 & $(0.028)$ & 0.086 & 0.929 & 0.177 & No Moderation \\
\hline \multicolumn{7}{|c|}{ Moderating Effect of Gender } \\
\hline $\mathrm{PU} \Rightarrow \mathrm{IEW}$ & $(0.067)$ & $(0.124)$ & $(0.010)$ & 1.993 & 0.023 & Moderation \\
\hline $\mathrm{PE} \Rightarrow \mathrm{IEW}$ & 0.054 & $(0.001)$ & 0.106 & 1.616 & 0.053 & Moderation \\
\hline $\mathrm{SI} \rightarrow \mathrm{IEW}$ & $(0.048)$ & $(0.117)$ & 0.010 & 1.256 & 0.105 & No Moderation \\
\hline $\mathrm{FC} \Rightarrow \mathrm{IEW}$ & $(0.078)$ & $(0.140)$ & $(0.015)$ & 2.022 & 0.022 & No Moderation \\
\hline $\mathrm{LM} \Rightarrow \mathrm{IEW}$ & 0.082 & 0.014 & 0.147 & 2.090 & 0.019 & Moderation \\
\hline $\mathrm{PT} \Rightarrow \mathrm{IEW}$ & 0.010 & $(0.041)$ & 0.074 & 0.285 & 0.388 & No Moderation \\
\hline \multicolumn{7}{|c|}{ Moderating Effect of Level of Education } \\
\hline PU $\Rightarrow$ IEW & 0.036 & $(0.039)$ & 0.115 & 0.788 & 0.216 & No Moderation \\
\hline $\mathrm{PE} \Rightarrow \mathrm{IEW}$ & 0.074 & $(0.007)$ & 0.161 & 1.422 & 0.078 & No Moderation \\
\hline $\mathrm{SI} \rightarrow \mathrm{IEW}$ & $(0.033)$ & $(0.129)$ & 0.061 & 0.565 & 0.286 & No Moderation \\
\hline $\mathrm{FC} \Rightarrow \mathrm{IEW}$ & $(0.066)$ & $(0.178)$ & 0.033 & 0.997 & 0.160 & No Moderation \\
\hline $\mathrm{LM} \Rightarrow \mathrm{IEW}$ & $(0.030)$ & $(0.146)$ & 0.073 & 0.445 & 0.328 & No Moderation \\
\hline $\mathrm{PT} \Rightarrow \mathrm{IEW}$ & 0.033 & $(0.055)$ & 0.123 & 0.614 & 0.270 & No Moderation \\
\hline
\end{tabular}

Note: PU: perceived usefulness; PE: perceived ease of use; SI: social influence; FC: facilitating conditions; LM: lifestyle compatibility; PT: perceived trust; IEW: intention to use an e-wallet; AEW: adoption of an e-wallet. Source: Author's data analysis.

\section{Discussion}

This study explored the factors that affected the adoption of an e-wallet through the intention to use an e-wallet and three moderating factors (age, gender, and education). This study verified the significantly positive effect displayed by perceived usefulness upon intention to use an e-wallet (H1). Similarly, Halttunen [57] asserted that it is important to intensify the intention amidst young consumers to use e-wallets by providing more information on the values and attitudes to create a positive mindset. As a result, consumers 
would consider online transactions as a useful and smart choice to purchase and even repurchase in the future. Therefore, provision of multifaceted knowledge to young consumers pertaining to digital content in particular is essential to highlight the usefulness of e-wallets. Perceived ease of use had a positive and significant relationship with an intention to use an e-wallet (H2). This mode of intention to use an e-wallet was determined by consumers' perception regarding the perceived of ease of use of technology. This study supports Chawla and Joshi's findings [25]. These findings point out that e-wallet providers such as banks and online stores should focus on the latest technologies that enable users to perform transactions effectively and efficiently. These savings in time, cost and ease of use will help in enhancing benefits, as e-wallets are perceived as easy to use by consumers. Social influence had a positive and significant effect on consumers' intention to use e-wallets (H3). This study supports the findings of Chaouali et al. [31]. This study reported that social influence such from family and friends affects consumers' mindsets on the use of new innovation products through technology services. The second most influential determinant of consumers' intentions, social influence becomes essential to encouraging consumers' intentions to use e-wallets, as it can build emotional and logical perspectives among consumers in developing countries. However, facilitating conditions (H4) had no significant effect on consumers' intentions to use an e-wallet as their preferred payment system in this study. This study demonstrated a different result from Peñarroja et al. [34]. This study indicates that facilitating conditions can encourage a consumer's intention to use an e-wallet with an online platform. In fact, facilitating conditions in certain cultures and environments cannot have a significant effect, as the existing infrastructure does not support such services [58]. Lifestyle compatibility had a positive and significant effect on the intention to use an e-wallet (H5). This study supports Shaw and Sergueeva's [36] findings, showing that it raises awareness of the usefulness of e-wallets to the consumers when e-wallets are compatible with the consumers' needs and lifestyles and they would have a willing to try out a new service. It is vital that the user would mostly use an e-wallet if the compatibility is high, as they can use it in their daily life and habits. Perceived trust also had a positive and significant effect on intention to use an e-wallet (H6). This study supports the findings of Wong and Mo [41] who stated that when consumers feel that the service provided is honest and reliable, it would mostly increase the consumer intention to use the service since they have high levels of belief in it. Consumers' trust can greatly affect the intention to use mobile service-by-service providers or payment services. Confidence in technologies contributes to improved assessments and attitudes towards technologies, in which the technology criteria meet the promise and are reliable and safe, which will have a positive effect on the intention to use these technologies. Intention to use e-wallets found a positive and significant effect on the adoption of e-wallets (H7). This study supports the findings of Lim et al. [19], who stated that the adoption of e-wallets is determined by consumers' intention to use them. Thus, consumers' intentions will provide understanding and knowledge of this cheaper, faster, and easier way of transferring funds through online transactions. Intention to use e-wallets has a positive and significant effect on the adoption of e-wallets (H8). This study supports the findings of Choi and Sun [45] that point out that the convenient use of e-wallets has already triggered the young generation to use them as payment instruments. The role of behavioral intention to use e-wallets, such as cashback and discounts, also has a strong impact on the actual use of e-wallets among young generation users.

Consumers' behavior intention can be influenced by their perceptions towards the environment to enhance the use of e-wallets. Lastly, this study supports previous studies $[47,49]$ which revealed that age and gender displayed partial moderation to strengthen the relationship between the predictors and the adoption of an e-wallet (H9 and H10). Hence, the age and gender of consumers can affect how consumers spend their e-money to purchase products, especially female attitudes towards the adoption of an e-wallet. However, education exhibited no moderating impact on consumers' behavior towards online 
purchases (see Table 7). However, education level (H11) in this study has no significant effect on the intention to use an e-wallet as their preferred payment system.

\section{Conclusions}

This study found that an intention to use an e-wallet mediates the effect of perceived usefulness, perceived ease of use, social influence, facilitating condition, lifestyle compatibility, and perceived trust on the adoption of an e-wallet. In addition, age, gender and education were found to have no moderating effect on this study from the perspective offered by the UTAUT. This study's novelty contributes to the existing literature. Firstly, it extends the UTAUT model by explaining the effects that various predictors have on the intention to use an e-wallet and adoption of e-wallets. This study offers a significant theoretical contribution to the UTAUT in particular, and to entrepreneurship theories in general, from exploring the adoption of e-wallets to perform cheaper, faster, easier, and safer transactions between buyers and sellers under the extended scope of the theory through the inclusion of the mediating effect of 'intention to use an e-wallet' on the correlations of perceived usefulness, perceived ease of use, social influence, facilitating condition, lifestyle compatibility, and perceived trust with the adoption of an e-wallet.

Furthermore, this study contributes to the theory domain by providing empirical evidence of the relationships of perceived usefulness and perceived ease of use with consumers' experience using e-wallets, social influence, facility condition, and lifestyle compatibility to explain the potential of young consumers' behavior in purchasing and repurchasing products, while using perceived trust to explain consumers' trust in the products. Lastly, this study addressed the scarcity of studies that focused on the adoption of e-wallets, especially during a pandemic, to purchase online products amidst young consumers. This study, hence, enriches the existing literature, particularly in the context of developing countries. The study outcomes may serve as a guideline to managers from emerging countries to devise effective strategies for the development, sale, and adoption of e-wallets by cooperating with banks or other online platform providers or companies offering online-based selling for accurate decision-making. Moreover, companies across developing countries should determine consumers' intentions toward, and their use of, ewallets. Essentially, this study investigates consumers' perspectives regarding the adoption of e-wallets, so as to make transactions cheaper, easier, faster, and safer.

As developing countries progress toward becoming developed nations, the future young generations, as companies as well as consumers with digital environmental awareness and knowledge, are likely to make an impact on the availability of online selling products and consumption behaviors. As this study shows the positive effects of perceived usefulness, perceived ease of use, social influence, facilitating condition, lifestyle compatibility, and perceived trust on intention to use e-wallet and adoption of e-wallet, future young generations will use more cashless transactions to purchase products and even repurchase in the future.

\section{Limitation}

Despite its contribution, this study is not without limitations. The findings and the implications of this study were derived from a cross-sectional research design. Hence, a longitudinal study is necessary to clarify the effects of temporal change. Second, during uncertain times, such as the COVID-19 pandemic, it is crucial to test the model across various countries with differing education levels and culture toward using e-wallets, so as to identify any difference or similarity across a range of business segments. Third, this study uses simple random sampling to obtain respondents, which may have a different effect than another sampling method.

\section{Future Research}

Future researchers could use this study to understand the factors that influence intention to use and the adoption of e-wallets. One of this study's limitations is that we 
did not include the premise of security guarantee and attitudes to influence consumer ethical behavior in our model [6,46]. Consumer behaviors are not only affected by internal perspective, but also by various other situational factors. Future research could attempt to integrate more constructs into the study's model, or implement the model in different cultures and geographical settings, in order to reveal a complex and more generalized understanding of the adoption and use of e-wallets-particularly among young generations in turbulent markets.

Supplementary Materials: The following are available online at https:/ / www.mdpi.com/2071-105 0/13/2/831/s1.

Author Contributions: M.Y., M.M., N.C.N. and N.R.Z. focused on conceptualization, methodology, resources, and writing-original draft preparation, A.A.M. focused on conceptualization, methodology, supervision, and writing-review and editing. All authors have read and agreed to the published version of the manuscript.

Funding: This research received no external funding.

Institutional Review Board Statement: This study has been performed in accordance with the Declaration of Helsinki.

Informed Consent Statement: Informed consent for participation was obtained from respondents who participated in the survey. For the respondents who participated the survey online (using google form), they were asked to read the ethical statement posted on the top of the form (There is no compensation for responding nor is there any known risk. In order to ensure that all information will remain confidential, please do not include your name. Participation is strictly voluntary and you may refuse to participate at any time) and proceed only if they agree. No data was collected from anyone under 18 years old.

Data Availability Statement: The data presented in this study are available in the Supplementary Material: Data File-Cashless Transection.csv.

Conflicts of Interest: The authors declare no conflict of interest.

\section{References}

1. Bibri, S.E. The IoT for smart sustainable cities of the future: An analytical framework for sensor-based big data applications for environmental sustainability. Sustain. Cities Soc. 2018, 38, 230-253. [CrossRef]

2. Capgemini. World Payment Report. 2019. Available online: https://worldpaymentsreport.com/wpcontent/uploads/sites/5/20 19/09/World-PaymentsReport-WPR-2019.pdf (accessed on 2 April 2020).

3. Li, C.; Mirosa, M.; Bremer, P.J. Review of Online Food Delivery Platforms and their Impacts on Sustainability. Sustainability 2020, 12, 5528. [CrossRef]

4. Sohail, A.; Shobhit, A.; Saurabh, S.; Akhilesh, V.; Varma, C.P. Development of Advance Digital Mobile Wallet. Int. J. Sci. Res. Dev. 2018, 6, 2758-2760.

5. Ganderbal, T. E-commerces; Department of Information Technology, Central University of Kashmir: Ganderbal, Kashmir, 2020; pp. 1-23.

6. Suleman, D.; Zuniarti, I. Sabil Consumer Decisions toward Fashion Product Shopping in Indonesia: The effects of Attitude, Perception of Ease of Use, Usefulness, and Trust. Manag. Dyn. Knowl. Econ. 2013, 7, 133-146. [CrossRef]

7. Rocha, V.; van Praag, M. Mind the gap: The role of gender in entrepreneurial career choice and social influence by founders. Strateg. Manag. J. 2020, 41, 841-866. [CrossRef]

8. Widodo, M.; Irawan, M.I.; Sukmono, R.A. Extending UTAUT2 to Explore Digital Wallet Adoption in Indonesia. In Proceedings of the 2019 International Conference on Information and Communications Technology (ICOIACT), Yogyakarta, Indonesia, 24-25 July 2019; pp. 878-883.

9. Belanche, D.; Flavián, M.; Pérez-Rueda, A. Mobile Apps Use and WOM in the Food Delivery Sector: The Role of Planned Behavior, Perceived Security and Customer Lifestyle Compatibility. Sustainability 2020, 12, 4275. [CrossRef]

10. Soodan, V.; Rana, A. Modeling customers' intention to use e-wallet in a developing nation: Extending UTAUT2 with security, privacy and savings. J. Electron. Commer. Organ. 2020, 18, 89-114. [CrossRef]

11. Venkatesh, V.; Thong, J.Y.; Xu, X. Consumer acceptance and use of information technology: Extending the unified theory of acceptance and use of technology. MIS Q. 2012, 36, 157-178. [CrossRef]

12. Statista McKinsey. Unlocking Indonesia's Digital Opportunity. 2020. Available online: http://www.mckinsey.com/industries/ consumer-packaged-goods/ourinsights/three-myths-about-growth-in-consumer-packaged-goods (accessed on 21 October 2020). 
13. Barata, A. Strengthening National Economic Growth and Equitable Income Through Sharia Digital Economy in Indonesia. J. Islam. Monet. Econ. Financ. 2019, 5, 145-168. [CrossRef]

14. International Trade Administration. Indonesian E-Wallet Market-Digital Payments Are Trending Upward in Indonesia. Available online: https:/ / www.trade.gov/market-intelligence/indonesia-e-wallet-market (accessed on 2 April 2020).

15. Ajzen, I. The theory of planned behavior. Organ. Behav. Hum. Decis. Process. 1991, 50, 179-211. [CrossRef]

16. Venkatesh, V.; Morris, M.G.; Davis, G.B.; Davis, F.D. User Acceptance of Information Technology: Toward a Unified View. MIS Q. 2003, 36, 425-478. [CrossRef]

17. Rahi, S.; Mansour, M.M.O.; Alghizzawi, M.; Alnaser, F.M. Integration of UTAUT model in internet banking adoption context: The mediating role of performance expectancy and effort expectancy. J. Res. Interact. Mark. 2019, 13, 411-435. [CrossRef]

18. Chandra, S.; Kumar, K.N. Exploring factors influencing organizational adoption of augmented reality in ecommerce: Empirical analysis using technology-organization-environment model. J. Electron. Commer. Res. 2018, 19, 237-265.

19. Lim, F.-W.; Ahmad, F.; Talib, A.N.A. Behavioural Intention towards Using Electronic Wallet: A Conceptual Framework in the Light of the Unified Theory of Acceptance and Use of Technology (UTAUT). Imp. J. Interdiscip. Res. 2019, 5, 79-86.

20. Ajmera, H.; Bhatt, V. Factors affecting the consumer's adoption of E-wallets in India: An empirical study. Alochana Chakra J. 2020, 9, 1081-1093.

21. Shankar, A.; Datta, B. Factors Affecting Mobile Payment Adoption Intention: An Indian Perspective. Glob. Bus. Rev. 2018, 19, S72-S89. [CrossRef]

22. Lwoga, E.T.; Lwoga, N.B. User Acceptance of Mobile Payment: The Effects of User-Centric Security, System Characteristics and Gender. Electron. J. Inf. Syst. Dev. Ctries. 2017, 81, 1-24. [CrossRef]

23. Liu, G.-S.; Tai, P.T. A Study of Factors Affecting the Intention to Use Mobile Payment Services in Vietnam. Econ. World 2016, 4, 249-273. [CrossRef]

24. Intarot, P. Influencing Factor in E-Wallet Acceptant and Use. Int. J. Bus. Adm. Stud. 2018, 4, 167-175.

25. Chawla, D.; Joshi, H. Role of Mediator in Examining the Influence of Antecedents of Mobile Wallet Adoption on Attitude and Intention. Glob. Bus. Rev. 2020. [CrossRef]

26. Hamid, A.A.; Razak, F.Z.A.; Abu Bakar, A.; Abdullah, W.S.W. The Effects of Perceived Usefulness and Perceived Ease of Use on Continuance Intention to Use E-Government. Procedia Econ. Finance. 2016, 35, 644-649. [CrossRef]

27. Grover, P.; Kar, A.K.; Janssen, M.; Ilavarasan, P.V. Perceived usefulness, ease of use and user acceptance of blockchain technology for digital transactions-insights from user-generated content on Twitter. Enterp. Inf. Syst. 2019, 13, 771-800. [CrossRef]

28. Peng, S.; Yang, A.; Cao, L.; Yu, S.; Xie, D. Social influence modeling using information theory in mobile social networks. Inf. Sci. 2017, 379, 146-159. [CrossRef]

29. Sarika, P.; Vasantha, S. Impact of mobile wallets on cashless transaction. Int. J. Recent Technol. Eng. 2019, 7, 1164-1171.

30. Martins, C.; Oliveira, T.; Popovič, A. Understanding the Internet banking adoption: A unified theory of acceptance and use of technology and perceived risk application. Int. J. Inf. Manag. 2014, 34, 1-13. [CrossRef]

31. Chaouali, W.; Ben Yahia, I.; Souiden, N. The interplay of counter-conformity motivation, social influence, and trust in customers intention to adopt Internet banking services: The case of an emerging country. J. Retail. Consum. Serv. 2016, 28, 209-218. [CrossRef]

32. Hossain, M.A.; Hasan, M.I.; Chan, C.; Ahmed, J.U. Predicting User Acceptance and Continuance Behaviour Towards Locationbased Services: The Moderating Effect of Facilitating Conditions on Behavioural Intention and Actual Use. Australas. J. Inf. Syst. 2017, 21, 1-22. [CrossRef]

33. Tarhini, A.; Elyas, T.; Akour, M.A.; Al-Salti, Z. Technology, Demographic Characteristics and E-Learning Acceptance: A Conceptual Model Based on Extended Technology Acceptance Model. High. Educ. Stud. 2016, 6, 72. [CrossRef]

34. Peñarroja, V.; Sánchez, J.; Gamero, N.; Orengo, V.; Abad, A.Z. The influence of organisational facilitating conditions and technology acceptance factors on the effectiveness of virtual communities of practice. Behav. Inf. Technol. 2019, 38, 845-857. [CrossRef]

35. Lin, H.-F. An empirical investigation of mobile banking adoption: The effect of innovation attributes and knowledge-based trust. Int. J. Inf. Manag. 2011, 31, 252-260. [CrossRef]

36. Shaw, N.; Sergueeva, K. The non-monetary benefits of mobile commerce: Extending UTAUT2 with perceived value. Int. J. Inf. Manag. 2019, 45, 44-55. [CrossRef]

37. Herrero, A.; Perez, A.; Bosque, I.R. Values and lifestyles in the adoption of new technologies applying VALS scale. Acad. Mark. Stud. J. 2014, 18, 37-56.

38. Hoque, M.Z.; Alam, M.N. What determines the purchase intention of liquid milk during a food security crisis? The role of perceived trust, knowledge, and risk. Sustainability 2018, 10, 3722. [CrossRef]

39. Sullivan, Y.W.; Kim, D.J. Assessing the effects of consumers' product evaluations and trust on repurchase intention in e-commerce environments. Int. J. Inf. Manag. 2018, 39, 199-219. [CrossRef]

40. Kim, S.Y.; Kim, J.U.; Park, S.C. The Effects of Perceived Value, Website Trust and Hotel Trust on Online Hotel Booking Intention. Sustainability 2017, 9, 2262. [CrossRef]

41. Wong, W.H.; Mo, W.Y. A Study of Consumer Intention of Mobile Payment in Hong Kong, Based on Perceived Risk, Perceived Trust, Perceived Security and Technological Acceptance Model. J. Adv. Manag. Sci. 2019, 7, 33-38. [CrossRef]

42. Wijayanthi, I. Behavioral Intention of Young Consumers towards E-Wallet Adoption: An Empirical Study among Indonesian Users. Russ. J. Agric. Socio-Econ. Sci. 2019, 85, 79-93. [CrossRef] 
43. Fishbein, M.; Ajzen, I. Predicting and Changing Behavior; Psychology Press Taylor \& Francis Group: New York, NY, USA, 2011.

44. Nikou, S.A.; Economides, A.A. Computers \& Education Mobile-based assessment: Investigating the factors that in fluence behavioral intention to use. Comput. Educ. 2017, 109, 56-73.

45. Choi, Y.; Sun, L. Reuse Intention of Third-Party Online Payments: A Focus on the Sustainable Factors of Alipay. Sustainability 2016, 8, 147. [CrossRef]

46. Xie, J.; Lin, R. Understanding the Adoption of Third-Party Online Payment: An Empirical Study of User Acceptance of Alipay in China. Master's Thesis, Jönköping University, Jönköping, Sweden, 2014. Available online: https://www.diva-portal.org/smash/ get/diva2:733072/fulltext01 (accessed on 22 November 2020).

47. Hwang, J.; Kim, H. Consequences of a green image of drone food delivery services: The moderating role of gender and age. Bus. Strat. Environ. 2019, 28, 872-884. [CrossRef]

48. Schmuck, D.; Matthes, J. How Anti-immigrant Right-wing Populist Advertisements Affect Young Voters: Symbolic Threats, Economic Threats and the Moderating Role of Education. J. Ethn. Migr. Stud. 2014, 41, 1577-1599. [CrossRef]

49. Cai, Z.; Fan, X.; Du, J. Gender and attitudes toward technology use: A meta-analysis. Comput. Educ. 2017, 105, 1-13. [CrossRef]

50. Pandey, S.; Chawla, D. Engaging m-commerce adopters in India: Exploring the two ends of the adoption continuum across four m-commerce categories. J. Enterp. Inf. Manag. 2019, 32, 191-210. [CrossRef]

51. Karjaluoto, H.; Shaikh, A.A.; Leppäniemi, M.; Luomala, R. Examining consumers' usage intention of contactless payment systems. Int. J. Bank Mark. 2019, 38, 332-351. [CrossRef]

52. Cepeda-Carrion, G.; Cegarra-Navarro, J.-G.; Cillo, V. Tips to use partial least squares structural equation modelling (PLS-SEM) in knowledge management. J. Knowl. Manag. 2019, 23, 67-89. [CrossRef]

53. Peng, D.X.; Lai, F. Using partial least squares in operations management research: A practical guideline and summary of past research. J. Oper. Manag. 2012, 30, 467-480. [CrossRef]

54. Hair, J.F., Jr.; Black, W.C.; Babin, B.J.; Andreson, R.E. Multivariate Data Analysis, 7th ed.; Pearson: Edinburgh, UK, 2014.

55. Fornell, C.; Larcker, D.F. Evaluating Structural Equation Models with Unobservable Variables and Measurement Error. J. Mark. Res. 1981, 18, 39-50. [CrossRef]

56. Kline, E.; Wilson, C.; Ereshefsky, S.; Tsuji, T.; Schiffman, J.; Pitts, S.; Reeves, G. Convergent and discriminant validity of attenuated psychosis screening tools. Schizophr. Res. 2012, 134, 49-53. [CrossRef]

57. Halttunen, V. Consumer Behavior in Digital Era General Aspects and Findings of Empirical Studies on Digital Music with a Retrospective Discussion. Ph.D. Thesis, University of Jyväskylä, Jyväskylän Yliopisto, Finland, 2016. Available online: https: / /jyx.jyu.fi/bitstream/handle/123456789/49620/1/978-951-39-6642-3_vaitos28052016.pdf (accessed on 22 November 2020).

58. Iskandar, Y.H.P.; Subramaniam, G.; Majid, M.I.A.; Ariff, A.M.; Rao, G.K.L. Predicting healthcare professionals' intention to use poison information system in a Malaysian public hospital. Health Inf. Sci. Syst. 2020, 8, 6. [CrossRef] 